\title{
'Shop as Home': The Meaning of Built Environment to Quality of Life of Shop Houses Residents in Medan, Indonesia
}

\author{
Wahyuni Zahrah", Nurlisa Ginting, Dwira N. Aulia, Amy Marisa \\ Department of Architecture, Faculty of Engineering, Universitas Sumatera Utara, Medan 20154, Indonesia
}

Received February 24, 2021; Revised April 19, 2021; Accepted May 11, 2021

\section{Cite This Paper in the following Citation Styles}

(a): [1] Wahyuni Zahrah, Nurlisa Ginting, Dwira N. Aulia, Amy Marisa , "'Shop as Home': The Meaning of Built Environment to Quality of Life of Shop Houses Residents in Medan, Indonesia," Civil Engineering and Architecture, Vol. 9, No. 3, pp. 932 - 948, 2021. DOI: 10.13189/cea.2021.090335.

(b): Wahyuni Zahrah, Nurlisa Ginting, Dwira N. Aulia, Amy Marisa (2021). 'Shop as Home': The Meaning of Built Environment to Quality of Life of Shop Houses Residents in Medan, Indonesia. Civil Engineering and Architecture, 9(3), 932 - 948. DOI: 10.13189/cea.2021.090335.

Copyright $\bigcirc 2021$ by authors, all rights reserved. Authors agree that this article remains permanently open access under the terms of the Creative Commons Attribution License 4.0 International License

\begin{abstract}
The shophouse is an urban house type that combines a residential and a shop in one building. This typology is commonly found in Medan and other cities in Indonesia due to its flexible space. Among the various studies on shophouses, minimal ones discuss the occupants' point of view. However, they are the most appropriate party to be asked about their living experiences in that multi-functional house. This study aims to explore the meaning of a shophouse for its residents. This is a qualitative research with a phenomenological approach that analyses the essence of a phenomenon based on the actual experiences of people live there. Ten participants were selected purposefully and their experiences were explored through in-depth interviews. This research applies the interpretative method by carrying out the steps of structured phenomenological analysis proposed by Moustakas. The investigation found that participants give meaning to a shophouse as 'where all life takes place.' There are some problems while living in the shophouse, but the dwellers can cope with it until they feel no significant obstacles while living in it to achieve the desired quality of life. The study results strengthen the study of the relationship between the built environment and the achievement of quality of life and provide a new perspective in assessing shop houses, particularly in Medan, Indonesia. This study has limitations because it focuses more on a person's personal experience living in a shophouse. However, the findings can make contribution
\end{abstract}

to urban planning activities, especially the development of shophouses to maintain urban residents' life quality. Besides, the results of this research can enrich the insight of architectural design in understanding occupants' preferences for a double-functioning building.

Keywords Meaning, Built Environment, Quality of Life, Shop Houses, Mixed Use, Living Experience

\section{Introduction}

Architects are the experts whose role is to provide advice about the most comfortable places for residents. To carry out this role, the architect should face two sides. The first is his/her view, as an educated person who has personal preferences about spatial design. The second is the occupants' personal view, with different culture and behavior backgrounds. To address these two sides, according to Rapoport [1], the most important thing is the occupants' point of view, the ones who live in the building. Facts show that less than $10 \%$ of the world's buildings were designed by architects $[1,2,3]$. It means that more built environments that exist today are the work of 'ordinary people'. Meanwhile, with its traditions and culture, society continues to develop, varying in different places and times. This condition encourages architects to understand how 
humans perceive their built environment, in various places, with various typologies.

The shophouse is one of the typical urban buildings that are very ancient. In the illustration of a Phoenician city in Africa, around $900 \mathrm{BC}$, one can find a type of shop-house: two-story building, narrow shape-extending to the back, business area on the ground floor, and residential area on the upper floor [4]. Typologies like this are still found in various parts of the world, such as Japan and Chinese shop houses, northern European merchants' houses, English terraced houses, and American small town corner stores with apartments at the upper level [5]. Many of Indonesia's shophouses come from Southern China, but the recent ones are different from their original form. One of the differences is the absence of an inner courtyard, which is crucial in providing passive thermal comfort [6] that can become a sustainable building model due to its passive design system [7].

Furthermore, shop houses also have weaknesses in terms of thermal $[6,8]$, and spatial comfort $[9,10]$. However, several studies have noted positive things in this typology, such as the uniqueness of the building facade $[11,12]$ the pedestrian-friendly mass [5] and the space between building blocks that can be a social space $[13,14]$. Among various studies on shophouses, it is hard to find a study that focuses on building occupants' viewpoint. Meanwhile, the residents are the most appropriate parties to be asked about what they feel living in a narrow, elongated building with two functions at once. This study intends to explore how the residents give meaning to that kind of built environment.

Meaning can be interpreted as communication between users and their environment, which results in human-environmental integration [14]. Meaning rises when a person reacts to their environment [1] and it is closely related to the socio-cultural, behavioral, and spatial dimensions $[15,16]$. The differences in various aspects of these dimensions can give different meanings. Rapoport [1] suggests three-level meaning of the built environment: high-level meaning, medium level meaning, and low-level meaning. High-level meanings relate to cosmology, cultural schemata, worldview, philosophical systems, sacred things, and the like. Middle-level meanings communicate identity, status, wealth, power, and the like, for example, latent things compared to the instrumental aspects of activities, behavior, and settings. Low-level meanings - instrumental meaning - are mnemonic cues /signs to determine usage in settings with social situations, expected behavior, and the like. At this level, there are aspects that enables users to behave and perform actions or activities appropriately and predictably; make co-action possible.

Studies on the meaning of the house examine the distinctiveness of the meaning given by a person related to gender [17], vernacular houses [18], the meaning of home for refugees [19] and elderly patients [20, 21]. Among these studies, it is hard to find the study about the meaning of a dual-function dwellings in developing urban areas, amidst the proliferation of this typology in various parts of big and small cities, especially in Indonesia [22]. It is necessary to study meaning in urban built environment in the mids of globalization over the world [23] so the dynamics of community's identity could be recognized.

In English, someone's living place can be described as 'house' or 'home'. 'House' is more associated with a physical container, while 'home' is a more emotional and spiritual entity, although they both talk about spatial aspects [21]. The home can also be viewed from several factors, such as social, psychological, and cultural dimension, including the key processes and the achievement of what one aspires to be [24]. In other words, home plays a role in achieving quality of life.

Quality of life is a unique concept that cannot be strictly defined because it depends on one's socio-cultural background. Experts agree that quality of life has two dimensions: an environmental dimension and a psychological dimension. From the environmental dimension, the quality of life is influenced by the quality of the built environment, including the condition of houses, housing, and facilities around it $[25,26,27,28]$. If we look in more detail, the house is one of the environmental aspects for its residents. Many studies have focused on the relationship between the built environment and quality of life. In these studies, the quality of the built environment is analyzed, which is claimed to have affected a person's quality of life. Such studies are conducted on a large scale and involve large areas and a large number of people [25, $26,27]$. These studies can also be conducted on a smaller, regional scale that concerns the quality of life of only a few people with specific characteristics, such as the elderly and patients who are in care [29]. A more diverse study is needed to see how different types of the built environment relate to users' lives. However, there is limited studies exploring the quality of life of those living in multiple-function shelters. How do residents perceive this type of house, and how does it relate to achieving their quality of life? The objective of the study is to investigate the meaning that occupants give to the shop-house building and its relation to achieving their desired quality of life.

\section{Methodology}

\subsection{Why Qualitative}

This research is a qualitative investigation using a phenomenological approach while the quantitative one is considered to have limitations in investigating the meaning and subjectivity of human experience [32,33]. As a result, there is a distortion in capturing the essence of the true meaning of the human experience [34]. This study aims to find the essence of the built environment meaning and its 
relation with quality of life through real and original experiences. Therefore, the qualitative approach is the most suitable method because its purpose is 'to clarify the meaning, and how humans are involved in making meaning, and thus, understanding the world', and 'focusing on exploration, search and explanation' [32, 35, 36]. Besides, qualitative research seeks to understand the context, circumstances, environment, and scope of a phenomenon that cannot be known with a quantitative approach [32].

\subsection{Phenomenology to Investigate Man-Built Environment Relationship}

In architectural and the built environment research, phenomenological studies are used to research why a place is vital to humans and how architectural design and the environment become a tool for place-making. In this case, phenomenology becomes an environmental-behavioral research method to unify difficult things between feelings and thoughts, between authentic experiences and secondary notes about those experiences [37]. Phenomena refers to objects or experiences a person has. The primary purpose of phenomenology is not a specific description of the phenomenon but rather it is used to find the fundamental things that are the essence of the phenomenon. In other words, phenomenology focuses on the specifics of phenomena that will lead to general qualities and characteristics that accurately describe the essence of these nature of phenomena, as experienced and interpreted in one's real life and experiences.

According to Seamon [37], the study of phenomenology is based on two fundamental assumptions: (1) humans and the environment are intimately bound in one 'package' and (2) humans and the environment are connected in a 'radical empiricism', where understanding is born from the researcher's personal awareness and sensitivity, rather than the usual secondary constructs as is a tradition in positive-science (a priori, theories, concepts, hypotheses, statistical measures of correlation).

\subsection{Setting}

In this study, the quality of life to be evaluated is related to the built environment, where humans interact with it intensively. A person uses the built environment not to inhabit but to 'dwelling in' as Heidegger stated [36]. This interaction is embedded by years of contact [37]

The typology of housing currently is more likely to be built in Indonesia is shop-houses (ruko). This building type is chosen with several considerations, as follows:

- Shophouses do not always pay attention to comfort requirements like housing in general, both thermally, visually, and spatially $[38,10]$

- With all its limitations (spatial, thermal, visual, and so on), shophouses are the favorite urban building typology, found in various parts of the world, have been built for centuries, and are still being built today $[5,38]$

- Most of the shophouses are designed independently, without an architect's intervention, so it is crucial to study them to understand better the tradition of the community and the needs for their built environment.

The shophouses as the object of study were chosen purposefully, with the following criteria:

- occupied as permanent, not temporary, residence

- inhabited for at least five years

- inhabited as a complete family residence

- owned, not rented, or loaned

- designed by the residents, not on the role or interference of the architect

\subsection{Participants}

In qualitative research, sampling is more often referred to as a participant or informant. The selection is carried out purposefully, in which participants are selected based on specific criteria that allow them to provide the most optimal information for study purposes [34]. In terms of the number of key informants, the phenomenological studies that have been carried out show many variations, from one person alone [39] to 325 people [40]. However, Dukes [39] suggests studying 3 to 10 individuals. The same thing was done in other studies, including Milleman [41] which was followed by 6 participants, and Doke-Kerns et al. [42] who also studied 6 participants.

There were 10 participants involved in this study, selected based on the following criteria:

- Inhabiting the built environment for more than five years and making the built environment a permanent residence, not a temporary residence, where daily life is carried out

- The owner of the built environment, which allows him to intervene or entirely modify the conditions of the built environment

- Already married that shows the achievement of a level of life, thus making it easier to evaluate the quality of life

- A person who has the most role in intervening, regulating, modifying the built environment, and applying the concepts of life in his/her residence

\subsection{Data Collection}

As previously explained, participants are determined based on specific criteria that allow exploring life experiences in a shop. The previous research [44] indicates two categories of shophouse occupants in Medan. The first category is people who have lived in the building for a long time, from generation to generation. This category comes from ethnic Chinese and lives in the shophouse area of Medan Old Town. The second category is those who live in 
shophouses but do not have a historical tradition of living in the shophouses as in Chinese society in general. These two categories describe their level of attachment (embodied) to the shop. Based on human relations theories with the surrounding built environment, both Ponty and Heidegger [36, 37] proposed that it is necessary to filter respondents based on their attachment level to the built environment. Those who have strong attachments have more interactive living experiences with their built environment. For this reason, the selected participants were those of Chinese ethnicity.

The selection of participants consists of two stages, as explained below.

\section{a. Respondent screening stage}

At this stage, questionnaires were distributed to the candidates who were known to live in the shophouses. The questionnaire asked about ownership, length of stay, marital status, and whether they live with a complete family. Data collection results of the first stage were obtained from respondents who met the criteria to be followed up with in-depth interviews. The questionnaire began to be distributed in mid-April 2020, through chain searches, from contact to contact, starting with the one in the first researcher's WhatsApp contact. From the list of potential participants, there were 13 questionnaires feedback, 11 of whom were willing to be interviewed. One person did not meet the criteria because she was not married.

\section{b. The follow-up detailed data collecting stage}

As a phenomenological study, this study uses in-depth interviews as the primary data collection method to explore participants' experiences, meanings, and perceptions of the built environment and quality of life [30, 31, 34, 46]. In a phenomenological study, interviews aim to reflect what participants have experienced, felt, and perceived about the built environment and quality of life. In the interview procedure, the following questions are asked:

- History and motivation of shophouse occupancy

- The meaning of shophouse for residents

- The character and achievement of residents' quality of life

- The meaning of the shophouse to the quality of life

Interviews were conducted between May and July 2020 with a duration of 26 to 46 minutes. Interviews were recorded on sound recordings, then transcribed verbatim under participant consent.

Besides, because this study also aims to understand the context, circumstances, environment, and scope of a phenomenon [30] other data collected are:

- Physical data of the built environment through visual surveys

- Space use (activity) data through interviews and visual surveys

- Participant demographic data (economic level, socio-cultural background, education level) through questionnaire.

\subsection{Data Analysis}

The analysis began with writing verbatim the results of the interview. The manuscripts of the interview results were then read repeatedly to capture the ideas expressed by the participants. The analysis used a structured method proposed by Moustakas [31] with the following steps:

- Transcription. Data files for each participant is coded to maintain the confidentiality of data, and audio recordings are transcribed into written exposure (verbatim)

- Epoche. Describing the researcher's experiences related to the phenomenon being studied

- Horizontalization. Describing the participants' statements about their experiences relevant to the experiences of the built environment and quality of life, and grouping statements that are considered equivalent. In this process, a list of meanings or units of meaning is identified, then grouped into themes, eliminating repeated and overlapping statements.

- Textural descriptions. Explaining what is experienced, felt, perceived on the built environment and quality of life.

- Structural descriptions. Describing how experiences occur or details of meanings and perceptions.

- The essence formulation. Integrating textural and structural descriptions and formulating the essence by presenting the primary aspects of the study.

\section{Result}

\subsection{Participants' Profiles}

All participants were Chinese, people who had historically experienced living in shophouses. However, two participants did not live in the shophouse before. Participants consisted of six women and four men, aged between 35 and 65 years. Most of them aged between 46 and 55 years. Most participants have an undergraduate degree, or at least a high school degree (Table 1). 
Table 1. Participant's profile

\begin{tabular}{|c|c|c|c|c|c|}
\hline Participant & Sex & Age & Business in shophouse & Income* & Dwelling in since \\
\hline 1 & Female & $46-55$ & Main income & $<5$ & 1994 \\
\hline 2 & Male & $>65$ & Main income & $20-25$ & 2000 \\
\hline 3 & Female & $46-55$ & Main income & $10-15$ & 1998 \\
\hline 4 & Female & $46-55$ & Side income & $<5$ & 2002 \\
\hline 5 & Female & $46-55$ & Side income & $<5$ & 1980 \\
\hline 6 & Female & $46-55$ & Main income & $10-15$ & 1992 \\
\hline 7 & Male & $46-55$ & Not in shophouse & $5-10$ & 2002 \\
\hline 8 & Male & $56-65$ & Main income & $10-15$ & 1998 \\
\hline 9 & Female & $36-45$ & Side income & $5-10$ & 2012 \\
\hline 10 & Male & $56-65$ & Main income & $>30$ & 2008 \\
\hline
\end{tabular}

*per month, in Million IDR

\subsection{Shophouses Characteristics}

The shop houses being studied are located in the city of Medan, the capital of the province of North Sumatra, Indonesia. The city is a trading city with a population of about 2.6 million. Seven of the ten shop houses surveyed are located in the business district, both in the center and on the fringe of the city. All of the seven buildings are functioned as places of business, both retail (five shop houses) and services (two shop houses). The other three shophouses are within the residential district block. Typologically, the shape of the building mass of all the shop houses is almost the same, both in the commercial area and in the residential area within the block. The difference is more in the interior layout, both in the placement of functions and furniture. All the shop houses that are the main business place the business area on the ground floor, as well as the two shophouses that open side businesses. One shop that opens a side business places the workshop on the second floor of the building. The conditions of shop houses examples for the two types of businesses can be seen in Figure 1 and 2.

\subsection{A Shophouse as a Place to Live and Comfortable Business Place}

Participants chose shop houses with various considerations, including affordable prices, easy-access locations, and relative position among public facilities, and functions that could accommodate living and trading needs (Table 2). With various answers, it was revealed that shophouses were both practical and comfortable places to do business and live simultaneously. It is practical because they can work and run a family living in one building. It is comfortable because the buildings are owned by themselves (no need to rent), enough space to support all family members' activities, easy access, and good neighbors.

"... Yes, if so, where to take shelter... yes, that is the main thing. Then, yes, can produce something. The important thing is we have a house... that is all. Instead of leasing, right? " (Participant 1)

"This shophouse, in my opinion, happens to be the right choice for us... Yes, one because it is comfortable here. Second, it is safe. Third, it is... easy. Easy going anywhere near... Yes. Third (fourth), there is one more. Living there happens to be all right in one environment. Neighbors are all well. " (Participant 2)

"... living in a shop is actually more comfortable because there is a shop below, you can see the children at the top, whether they have not returned yet ... it's definitely more comfortable, we want to go in and out more comfortably ... business can be as well ..." (Participant 6)

"Yes, that is good... there is business... even looking for a vehicle is easy... the good thing is that... " (Participant 3)

"Since I have a small and side business to do at home, I can while working to earn money on the side and take care of the children from the house... in my opinion. It is an extraordinary thing because it can be done at once." (Participant 4)

"... We are feeling right here. Everywhere is close... if you want to move to a housing complex (gated housing), you can't walk if you don't have a car. If here... we want to go to a nearby mall... just walk..." (Participant 5) 

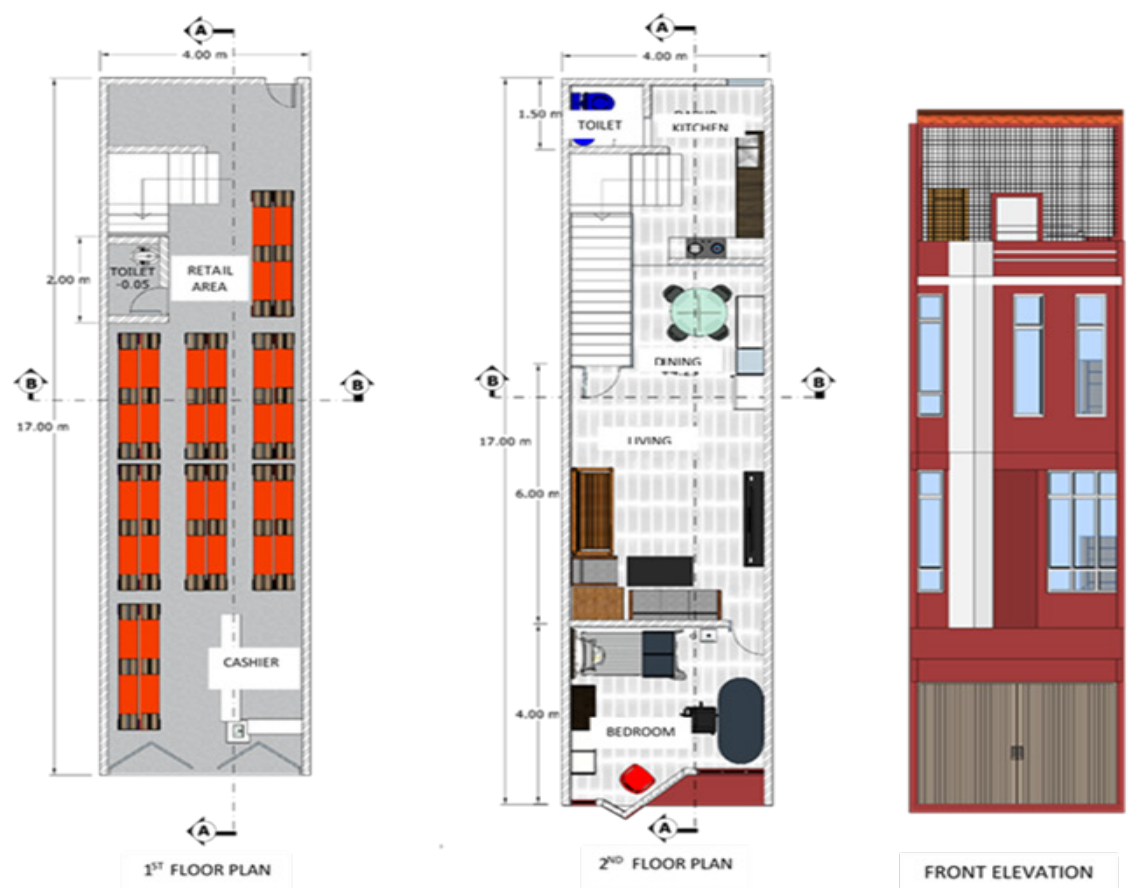

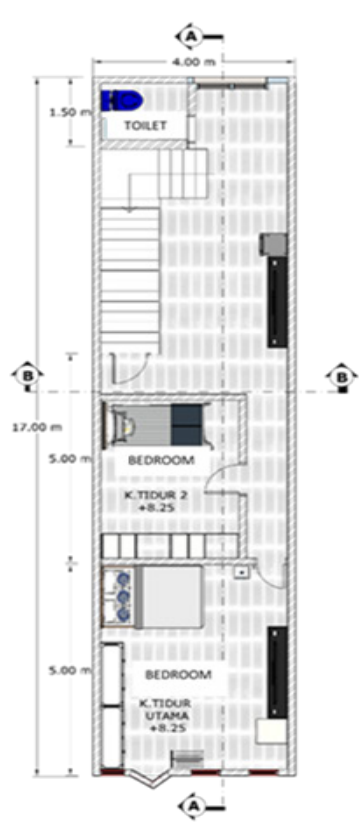

$3^{\text {rd }}$ FLOOR PLAN

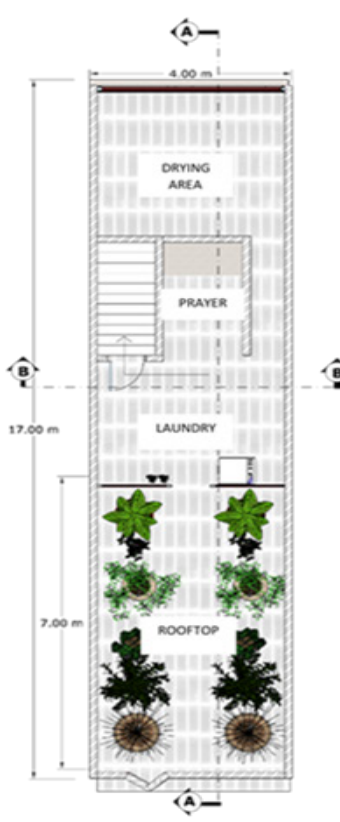

ROOFTOP PLAN

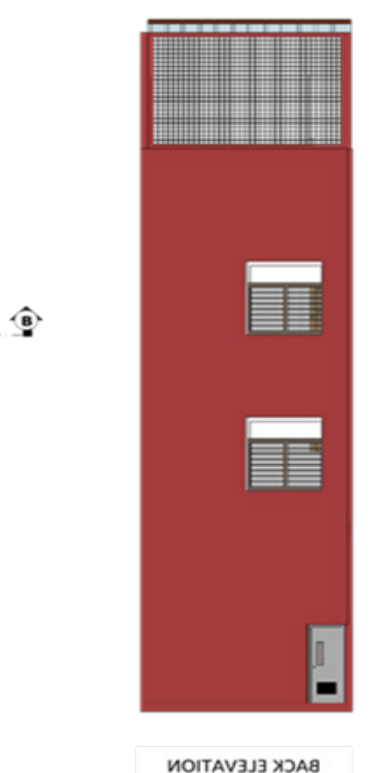

BACK ELEVATION
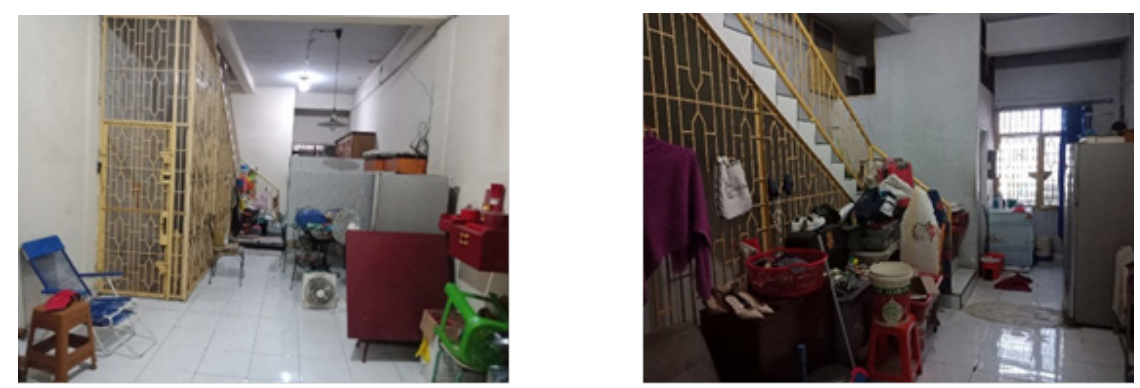

INTERIOR OF $2^{\mathrm{ND}}$ FLOOR

Figure 1. Participants 8 's shophouse: the example of shophouse as primary business, located in business district 


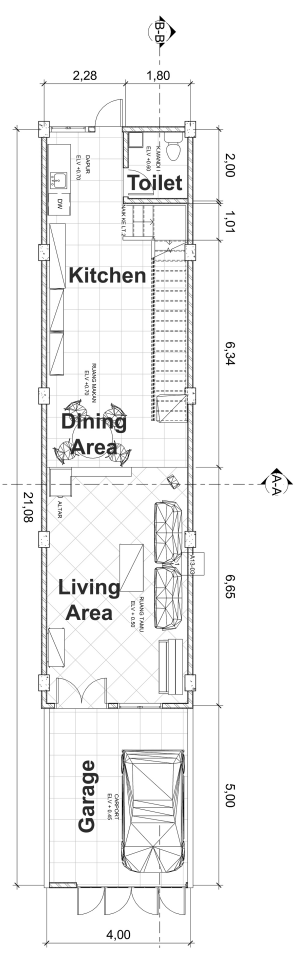

First Floor Plan

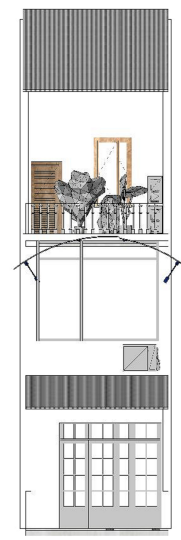

Front Elevation

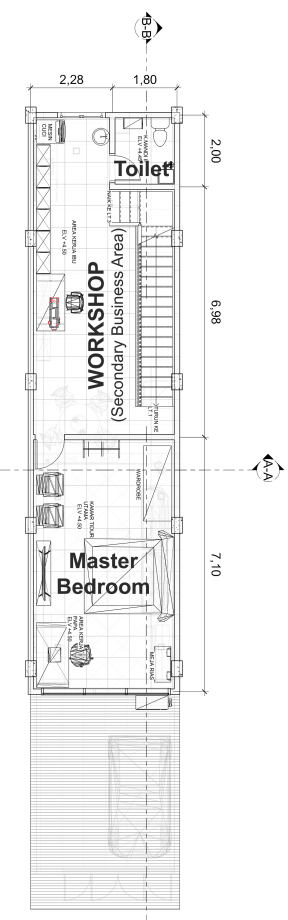

Second Floor Plan

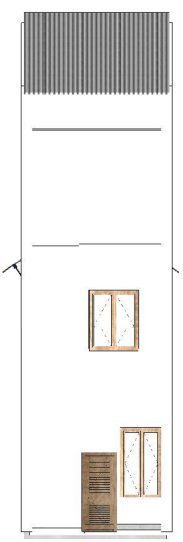

Back Elevation

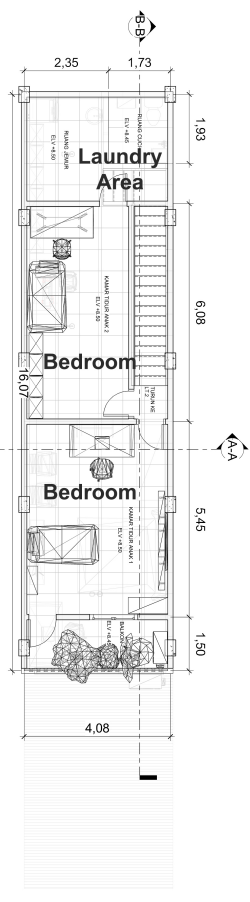

Third Floor Plan

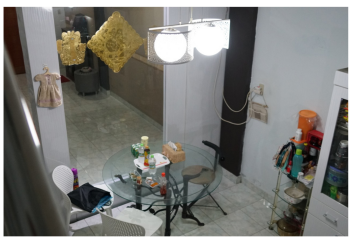

Dining Area

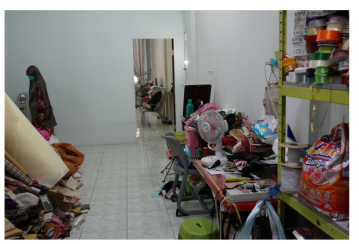

Workshop Area

Figure 2. Participants 4's shophouse: the example of shophouse as secondary business, located inside housing blocks

3.4. There are Several Problems in the Building, But It is Not a Big Obstacle for Them in Their Activities

The interviews with participants indicated several deficiencies in the shop building, including leaks, dust, noise, narrow and hot spaces, and problems with access to upper floor, which forced residents to go up and downstairs. It became a difficulty, especially for elderly residents. The other disadvantage was the expensive operational cost, including high taxes.

"I think this house during my 15 years of life I think is getting narrower, maybe that's how it is... the more we buy things every day. The house is not big enough." (Participant 4)

"So, so ... what, how come, later on, a road like this, it's very close to the road, isn't it noisy? Noisy.... We want to be comfortable, right? It is noisy here, much traffic... " (Participants 1)

"... Lots of dust, noise... Then, anything is expensive, water must be expensive, what it is ... This was the first time I was married at 9 sleep, at 11 at night I still woke up because of the noise. In the past that was really terrible ... Noises... I didn't sleep... At 11 o'clock 12 I still woke up..." (Participant 3)

"Ordinary, it's just... however... we are living by the roadside... noise..." (Participant 8)

"There is also a leak, soaking in water, right? Most of the shophouses are like that... it leaks ..." (Participant 7)

"Yes, the needs are just right ... the ones in the renovation are the ones that leak... because the house is old, right? $2005 \ldots$ then you know that if the house is attached (to another building), there must be something leaking, 
especially the empty side right there... " (Participant 9)

"There are no obstacles, but if we get old... when we go up and down, it does hurt a bit... if we go up and down our knees, hurt a bit... (Participant 6)

"Yes... Then while we get older, going up and downstairs is tiring ..." (Participant 9)

"The problem is ... the floor is very high ... It's so high, so my mom is unwilling to come ... Go up to the third floor... she can't take it anymore... " (Participant 10)

However, with these problems, the participants could still carry out their activities well. If possible, they solved these problems by changing the environment. For example, they renovated or added more rooms, arranging common spaces to be multi-functional, adjusting light, applying easily movable furniture for multi-functional spaces, and installing artificial air conditioners to support the comfort of the bedroom. Besides, they also made themselves adapting, trying to accept the existing conditions so that finally, the obstacles did not become a problem anymore. The participants stated that they were satisfied with living in the shophouses and had fulfilled the activity needs.

"Appropriate... This building is appropriate. If it's ideal, not yet... yes... because I chose the shophouse because it was right for it. Are we satisfied enough? Yea... that is human... we are never satisfied la. " (Participant 2)

"... relatively safe.... Only one problem, in the 1970 s, our parents built this house with only one bathroom, only on the lower floor ... yes, if we want to renovate again the obstacles are also quite difficult, that's the problem we face. " (Participant 5)

"...in the past, it was hot because... here, right behind this... before (the back area) was built... it was cooler, there was air circulation... but since it was built it became a bit hot, the second floor was a bit stuffy, but the third floor is still not bad. " (Participant 8)

"...We don't have any difficulties (living in a shophouse). Nothing. The neighbors are all good too... Yes, they are all friendly. It's good... Yes, it's comfortable la. It's good." (Participant 1)

"We want it or not, we are satisfied, we are not ... what else should we do ... about ... 80\% (satisfied) " (Participant 3)

"Everything has been fulfilled, it's just a matter of waiting for our children to build their own house, and if we move from here... we don't want to move anymore, it's safe and comfortable here. It's better if we live here, as soon as we open the door, we can go anywhere... " (Participant 5)

"... It was perfect here... there used to be many problems... yes that... customer problems, money problems... ruined... up to three years... very bad... but that is, we will still survive... yes, it might be the influence of patience right? " (Participant 10)

Table 2. Shop houses' meaning

\begin{tabular}{|c|c|c|}
\hline Themes & Sub-themes & Participants \\
\hline \multirow{2}{*}{ Business in shophouses } & As the main income & $1,2,3,6,8,10$ \\
\hline & As the side income & $4,5,9$ \\
\hline \multirow{5}{*}{$\begin{array}{c}\text { Motivation and history of } \\
\text { dwelling in }\end{array}$} & Having home and business in one building & $2,8,10$ \\
\hline & Location and distance to the public facility & $2,7,9$ \\
\hline & Distance to working place & 4,5 \\
\hline & Affordable & $2,4,9$ \\
\hline & Marriage consequences & $3,5,6$ \\
\hline \multirow{4}{*}{ Renovation } & All rooms (no room-division in the beginning) & $7,8,9,10$ \\
\hline & Some of rooms addition (part of rooms was available in the beginning) & 2,4 \\
\hline & Just adding one or two bedrooms, the other rooms were available & $1,3,5$ \\
\hline & Changing wall paint & $1,2,4,6$ \\
\hline \multirow{5}{*}{ The most important room } & Store & 3,8 \\
\hline & Kitchen & $4,5,9$ \\
\hline & Bedrooms & $1,6,9$ \\
\hline & All rooms & $1,2,10$ \\
\hline & Bathroom & 7 \\
\hline \multirow{4}{*}{$\begin{array}{l}\text { Participants' activities in } \\
\text { shophouses }\end{array}$} & Running business & All participants \\
\hline & Cooking & $3,4,5,9,8$ \\
\hline & Accompanying and controlling kid's learning & All participants \\
\hline & Family gathering & All participants \\
\hline \multirow{7}{*}{ Meaning expression } & Shelter & 1 \\
\hline & Bussiness place & $1,3,8,10$ \\
\hline & Own building, no need to rent & $1,2,3,7,8,9,10$ \\
\hline & Appropriate & 2 \\
\hline & Comfortable, pleasant, good place & $1,3,5,6$ \\
\hline & Nice neighbors & $2,5,6,7$ \\
\hline & Close to everywhere, good location & All participants \\
\hline
\end{tabular}




\subsection{Still Wish Another Type of House for Old Age}

Except for participant 5, all participants stated that they want, when they are old and their children are successful, to live in a one-story villa or apartment type house. That is a type of house that they think is more ideal, free from shophouse problems: noise, too narrow space, no yard, and having to go up and downstairs.

"Actually, to be honest, it's better if we live in a simple flat house but wide enough, we want eight by thirty meters, or ten by thirty meters, no need to be terraced... there is a garage. Basically, there are four rooms, right ..." (Participant 3)

"But if there is a fortune, I want a bigger one. I want a house in a complex (gated housing) with security guards... In a house complex, maybe the house has a different size, right ... so if I want, the size can be over six (meters), so it's a bit wide. We can arrange the space neatly, put things in, for example, load accessories... then want an outdoor area that we can plant... so if I cook, I can see the garden, dine together there, and enjoy coffee together. " (Participant 4)

"... I definitely want to (own and live in a villa type house), because when we are old... we live in a complex (gated housing), we can relax... there is possibility to plant plants... a house for old age... can't keep in this shop house..." (Participant 8)

"Yes ... indeed our plan is there ... to live and work ... but actually, if this is an experience, the business is in a shophouse ... we have to live somewhere else ... because later when we get old... what if there is a problem in the knee (making it difficult to go up and down the stairs) ... yes at least if we are old, right ... Now I prefer to live in an apartment ... take the elevator ... not take the stairs anymore ... " (Participant 10)

\subsection{The Quality of Life of the Residents of the Shophouse}

The participants stated that the quality of life they wanted was the economic sufficiency, health, and success of the children to live independently. All participants stated that the quality of life had been fulfilled when their stay in the shop house.

\subsubsection{Economic prosperity}

Six out of ten participants stated that the character of the quality of life is the achievement of economic prosperity, which is marked by the fulfillment of basic necessities for food, owning their own house, and sufficient costs for children's education. By doing business in the shop, both as a primary and side income, participants can earn up to 30 million IDR (Table 1). An income that is far above the average population of Indonesia, which is around 4.9 million per month.

".... (Quality of life is) you can work independently, you can earn your own money, you can be happy..." (Participant 3)
"... the important thing is that life can run smoothly, God can provide sustenance, yes, we can handle our children in school, we can meet the cost of living, right ... every day we can eat, we are grateful ... the cost of living can be met..." (Participant 8)

\subsubsection{Health}

Health is also a character of life quality expressed by the participants. Efforts to maintain health are carried out by consuming healthy foods, in which some of the participants cook their own food. Besides that, they also do sports.

"A quality life, in my opinion, the most important thing is to be given health. Because of how much money you have, you can't do anything if you are not healthy... " (Participant 4)

"As I said: health, at most is number one for me ... " (Participant 8)

"Quality is yes ... yes, having a family, having a business, being healthy, so if possible, we have our own house ..." (Participant 10)

\subsubsection{The success of children}

Most of the participants stated that successful children were one of the characteristics of quality of life. Participants really expected their children to succeed in education, be independent, have their own business, and have a right attitude. The participants control their children's education both at school and at home. They kept communicating with children when together at home. Participants also carried out assistance and supervision for children's learning, both in their respective rooms and in the common room. The room was multi-functional that can function as an office, as a dining room, a gathering place, and a place to receive guests. These multi-functional rooms are quite flexible where they put the light-movable furniture.

"... Gathering with family, children, grandchildren, yes... Yes, if possible... children... we put our hopes on children. The important thing is that children can develop their business, yes. " (Participant 1)

"... (What makes us happy) the children are grown, are independent... The important thing is that the children have an education..." (Participant 5)

".. It is not money that is everything, but the meaning of being happy is what I actually think about... 75\% (has been achieved)... Children, all eight children are lovely. Nothing has a bad attitude... All of them live independently. That is happiness as a parent." (Participant 2)

"Quality is yes ... yes, having a family, having a business, being healthy, so if possible, we have our own house..." (Participant 10)

\subsubsection{Grateful}

All participants have spoken about their achievement of quality of life with expressions of gratitude. With various limitations of the shophouses, they accepted it as it was. 
Everything obtained while living in the building, including ownership of a house, a strategic location, activities that could run smoothly, and various obstacles, were considered grateful. Some of them connected this feeling by their Buddhism religion.

"... That is great because we have our own business to run. No need to rent anymore, we have our own shop ...very grateful." (Participant 3 )

"It is actually a bit difficult if you want the ideal story ... Yes, my dream was to be quite a simple villa house, want a happy family, right? However, sometimes it is not possible in this household to be the ideal. We have experienced many different development processes." (Participant 2)

"(Quality of life) can gather with family, have a permanent place to live, close to everywhere, can be used for business too.... Not bad... it has been achieved. We have been given health and economic conditions that are adequate now ... It has been (achieved). Hopefully, it is ... grateful. "

"(Quality of life) yes everything is fulfilled... yes health, family gatherings... the important thing is... yes, be grateful... (it has been achieved)... yes we are religious people... it should have been achieved... (quality life)..." (Participant 6)

"Yes, the important thing is that it runs smoothly. God can provide sustenance, yes... We can handle our children's education and living expenses, right ... We are grateful for our daily meals ... Yes, I am already grateful..." (Participant 7)

"... I am not a person who has so many demands, you can say it is a small car, come on, a small house, come on, there is additional fortune, okay, that's okay ..." (Participant 9)

"Satisfied or not satisfied, so we have to be very grateful, to be grateful we can stay here, take care for the children, be happy, there must be a search for success, be happy to be grateful, we can eat something, we must be grateful ... the first is, we can be grateful for sure we can be happy, automatically we are happy... " (Participant 8)

"Yes, it seems to be human nature, if we want to be grateful, all can be grateful ... if you want to complain, you should complain about everything ... ha, that's the experience of life ... I used to complain too ... but now I follow Buddhism...it means we planted beforehand now we harvest ... reap ... right ... " (Participant 10)

\section{Discussion}

Home is a fundamental thing for humans where life is centered. Being at home is a fundamental activity compared to other activities such as working or traveling. Being human is by living in the house [21, 45]. Rapoport [45] states that every house is basically designed. It means that a person will make all efforts to implement his ideals of life in the built environment, starting from imaginary and conceptual things to materializing the spaces and forms inhabited, used, and perceived. Thus, home is a place where someone feels that their life is cared for, and finally, they are happy $[46,47,48,49]$. The quality of human life is tied to a place, in this case, home [46]. This study found that shophouses, for participants, are the places where their entire lives take place, to achieve the character of the quality of life they aspire to, namely economic adequacy, health, and independent children. These characteristics are not different from that of other families that are mostly based on the 'golden triangle': income, aspiration, and social relationship [50]. The uniqueness is that efforts to achieve these goals are carried out by consciously choosing one double-functioning building, where they can run a business and take care of a family, only under one roof. It can happen because the residents give the meaning of this building as a house, both at lower and middle level of meaning [1]. The low-level one is the tangible perspective shown by the physical aspects and activities that can easily be seen. The middle level is the intangible-latent aspects regarding their aspirations about their ideals.

Meaning does not come immediately but is the result of intensive interaction with the environment. This study found that this interaction can last a long time, which has been started even before occupying the building. For some participants, the meaning of the shop house became a place to live, could be based on their childhood experiences, where the family had lived in the shophouse from generation to generation. Other participants started giving meaning for the shophouse when they initiated a new life by marrying their husbands who have lived in these places. Meanwhile, some participants had never lived in the shophouses during their childhood, but they choose the building as their living place because of their dreams for the future. These are the phenomenon of living in a shophouse revealed from participants' experiences, preparing for the beginning of their family life. When the shophouse is then occupied, the participants continue to undergo interactions. Ideals are still held firmly, and when there are shophouse obstacles, they try to be overcome. They do cope with keeping achieving the desired quality of life. If possible, they change the environment through the arrangement of space, furniture, and materials. If they can not, the participants accepted all conditions as a consequence of their initial choice. They accept these obstacles with grateful hearts because the desired quality of life can be reached gradually. They feel 'comfortable, felt good' living in this building that is 'the appropriate one' according to what is needed.

\subsection{The Meaning of Shophouses and the Achievement of Economic Adequacy}

The achievement of the participants' quality of life is directly or indirectly relates to how they give meaning to the buildings. A shophouse, which has meaning as a place for a business, is essential in obtaining income to achieve 
economic prosperity. For participants who explicitly stated this building as their primary business place, the essential things supporting that function become their top priority. For that, location is crucial. The most accessible location is a significant consideration. It can be seen from how Participant 8's family surveyed locations expected to support their business after deciding to buy the shop house itself, from previously rented, and separated business and residence function. Participant 8 shared how difficult it was when houses and shops were separated, especially in taking care of families and children. After considering several alternative locations, he chose the shophouses on the main road, the inter-city highway. This effort did not work out quickly. The lonely situation at the beginning was something that had to be dealt with patiently. Participant 1 also said the same thing. Initially, no customers were coming. Nevertheless, she later revealed that the most enjoyable experience was when the location got busier, meaning that business opportunities were getting better.

Participants 10 also started a business from zero with various challenges. He continued business in the new place after previously having to move from the former business place, which has already been in a strategic location, on the side of the city artery road. Same with Participant 8, Participant 10 also rented a shop and separated from the house previously. In the previous rental shop, he also faced a difficult period of being no customers initially; he found the right strategy until then his business was going to be progressed. Unfortunately, when the business was running well, the shop owner he rented did not allow him to continue the rent. Thus, he had to find a new location. Once the location moved to the current place, the previous customer no longer shopped at the store. Participant 10 started almost all over again. The early few years were difficult times, including the discomfort inside the building.

Another consequence of choosing a location is that it is noise. It was experienced by all participants who made the shophouses their primary place of business. Most of the the position of building was right on the main road's edge, both arterial and collector roads. Participant 8's stated that noise was one of the weaknesses, and when he stayed at a relative's house in the complex (gated housing), "I felt more calmness." Participant 1 and Participant 3 also felt this way. Participant 1, who has lived in the shophouse since childhood, also felt the noise. Participant 3, who lived in a single house in a quiet residential area before marriage, experienced a period where she could not sleep well because of the noise. Participant 3 revealed how the noise disturbs her in the beginning. However, over time she adapted, and now this is not considered a problem anymore.

For participants who prioritize a place of business and start life in an empty-quiet building area, they keep surviving numerous consequences for the sake of location. Participants who entered an established shop house, because it had already become the place of their husband's family business, also keep the location that is considered profitable. It can be seen from the experience of Participant 3 that runs the restaurant. The place has been well known to the community for a long time since her husband's grandfather is still in charge. The place is easily accessible because it is located on the city's main artery road. She said he had to accept the noisy, cramped, and expensive conditions of the shophouses. Slightly different, Participant 6's shophouse is not precisely on the side of an arterial road or a primary collector but is in the old commercial district of Medan. This location is not as noisy as the shophouses on an arterial road, but it is still easily accessible. Furthermore, according to her, the shop is now comfortable and safe due to its near position to a mosque and neighborhood security post.

The meaning of a shophouse as a place of business makes the business area an essential priority. The consequence is the area for the house function is limited. Thus, all participants apply multi-functional spaces. They do not have a particular room to receive guests. The room is integrated into the family room and or dining room. For example, in Participant 2's house, the living room, office, and family gathering are the same room, which is used interchangeably. At Participant 9's shophouse, the private lessons area was also used as a car garage. This space blends with the dining room that was also utilized as a living room (Figure 3). 


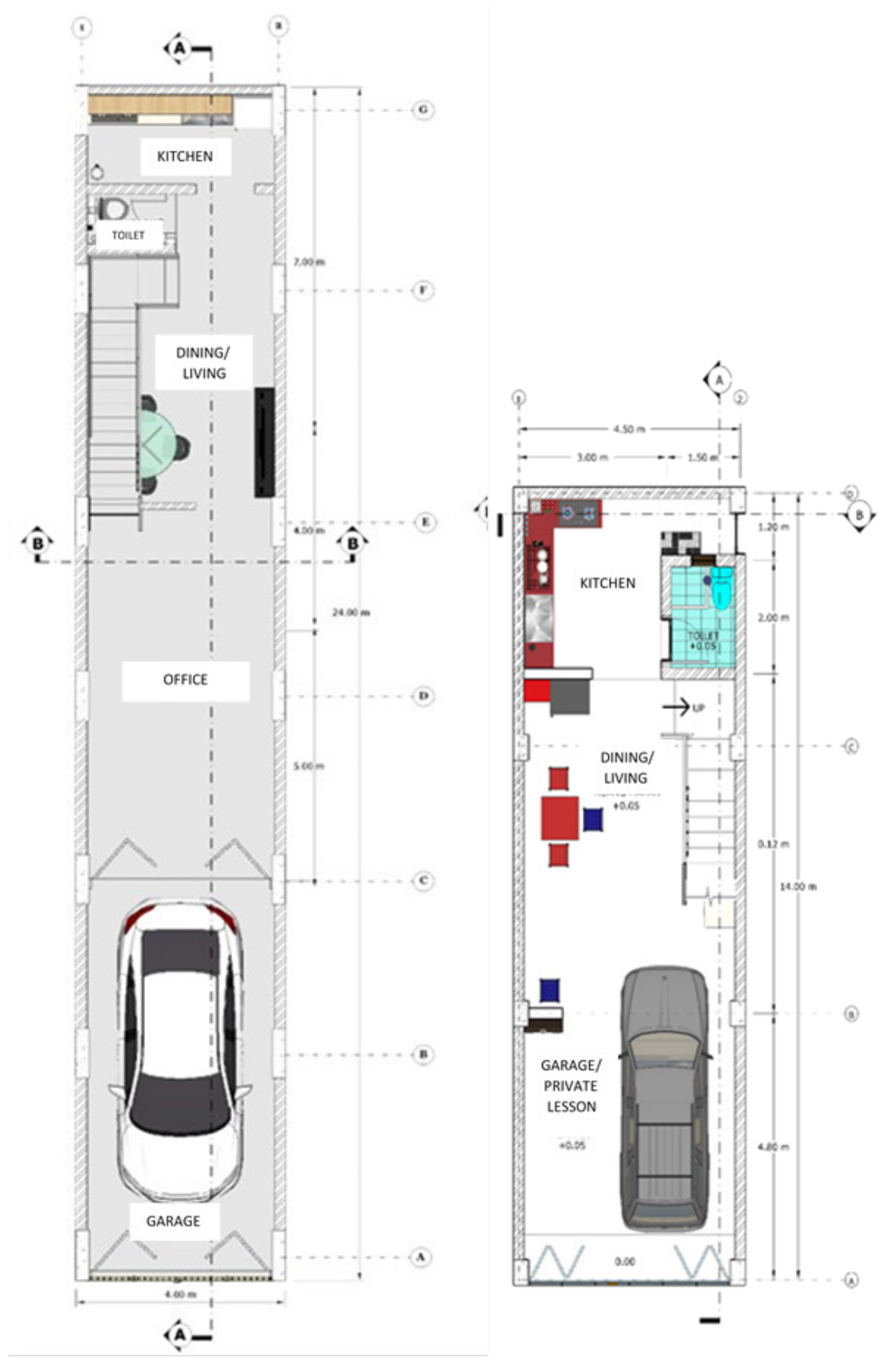

Figure 3. The first floor plan of Participant 2's (left) and Participants 9's (right) Shophouse

As a priority for this business area on the ground floor, the rooms of the houses' must be located on the upper floors, especially the bedrooms. In this condition, participants perform both adaptation and adjustment. Adaptation is a condition in which humans adapt their behavior to the built environment, while the adjustment is made by changing the environment to accommodate the behavior [50]. One example of adaptations is done by spending time at a space longer than the other area. In Participant 5's house, the elderly family members spend most of their time during the day in the ground floor sitting room, including taking naps to avoid keeping up and down the stairs. When they want to get rest at night, they go upstairs to the bedroom. Another adaptation is how some of the shop's shortcomings, such as noise, limited openings, and should go up and downstairs, can be accepted and considered normal so that it is no longer a problem. It means that the residents can perform daily activities comfortably. All participants stated that the shop was 'comfortable, it feels good.' 

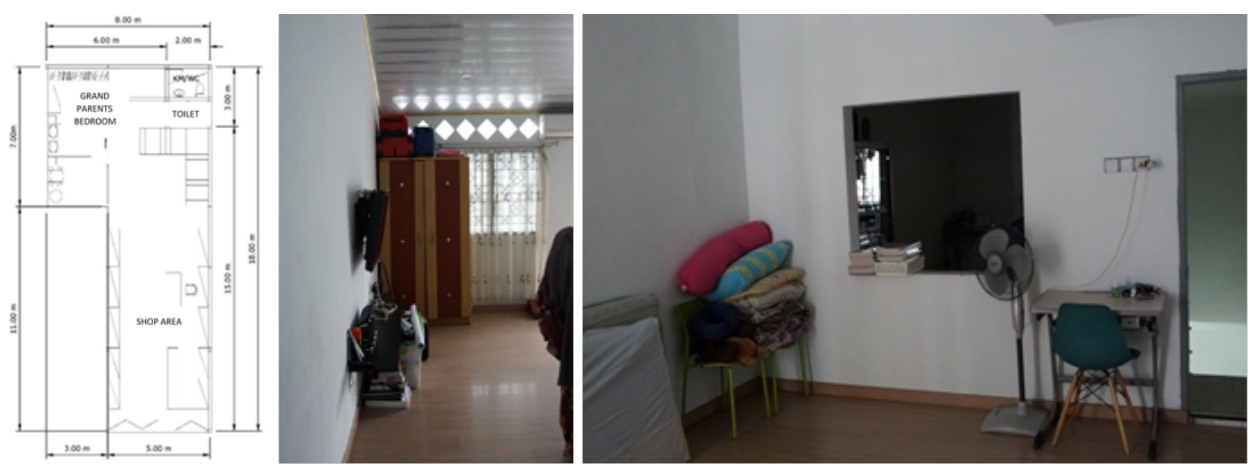

Figure 4. The first floor plan of Participant 6's shophouse (left) and the 'connecting opening' of two bedrooms in Particiant 4's shophouse (right)

The residents perform adjustments by changing part of the interior zones. With limited expansion space, they make the arrangement as efficiently as possible. The integration of the dining room - family sitting room living room, is one example. In some shophouses, the occupants share a space for various daily and occasional activities, such as celebrating birthdays and religious holidays. Another adjustment is modifying part of the ground floor into a bedroom for elderly family members because they no longer can go up and downstairs. Participant 6 makes this change by moving grandparents' rooms to the ground floor, the area that was used as storage before (Figure 4 - left).

Meanwhile, at Participant 4's house, the limited windows were resolved by creating a connecting opening between the two children's rooms (Figure 2 - Right). There is a 'connecting opening' between two kid's bedrooms, so that the room on the backside, which does not have an opening, can be connected to the source of air and light in the front room. This solution still has a consequence of reducing privacy. In several participants' shophouses, such as Participant 3, Participant 5, and Participant 6, additional rooms were made on the rooftop (Figure 3). Due to the addition, the two bedrooms can be attached, so one of the rooms no longer has a window. Adjustment applied in all shophouses is installing artificial cooling for all bedrooms because most of the rooms have no adequate ventilation. With this equipment, the thermal comfort problem is fixed, and it properly accommodates its function as a place for taking a rest. Almost all participants stated that the bedroom is their favorite place (Table 2).

All participants stated that they had achieved economic adequacy since they stayed in the shophouses, varied between 8 to 20 years. They can own a house, can pay for daily living and their children's education. It means that the shophouse, which has meaning as a place of business and the primary source of income, is the central infrastructure in achieving quality of life. All participants stated that shophouses have a vital role in obtaining the quality of life they aspire.

\subsection{The Meaning of Shop Houses and the Achievement of Children's Success}

With various expressions, the participants stated that the meaning of a shophouse is a home, which can be seen from the functions of space, activities, and certainty of property rights. The function in the shophouses is the same as the other house buildings typology. There is a sitting room, dining room, kitchen, and bedrooms. In these spaces, participants lead family life: providing food, gathering together, resting, supervising, and accompanying the children to study. Although family life is a joint responsibility of husband and wife, domestic activities are more dominated by the mother's role. The main challenge for women with families is their dual role, as women with their jobs in the public sphere and wives and mothers who should manage and take care of their husbands and children in the domestic sphere [51, 52]. In this study, almost all wives run a business together with their husbands as their primary income source. That is, they spend their time running the shop. Participant 1, Participant 6, Participant 8 's wife, and Participant 10's wife are all parties who play a role in running the business. Meanwhile, Participants 4 and Participants 9 are housewives who run a side business in a shop. Participant 5 and Participant 2's wives are not involved in her husband's business. Only Participant 3 has a job outside the shop as a teacher. However, overall, it can be said that all the wives in this study were housewives with domestic roles.

Some participants stated that living in a multi-function shop house made the dual role easier to perform. Participant 8 and his wife shared that there was quite a hassle when the houses and shops were separated. They had to deal with road congestion, take the children to the shop, or first take them to school. However, when they settled in this shophouse, this problem got a solution. Going to the store is easy just by downstairs to the ground floor; watching the children is as simple as going upstairs. Participant 6 talks about how she felt the easy moving from shop to house, especially in the early family years, when the children were still little kids and needed intensive supervision. 
Routines like this also take place in the lives of other families. Children grow and develop both inside buildings and in the surrounding environment. Mothers and fathers who work in shophouses can easily switch their roles in just one building. Participant 5 talks about the neighborhood where he lives, how his children have neighbors' children as playmates. The public road in front of the shop is also used for children to play.

"... So far, these children just enjoy this house. Every night we get together. At 7 a.m., they go to school, back home at 7 p.m. If necessary, they study again at home. Every Saturday, they gather with the neighbors' children in front of this house, playing football. " (Participant 6)

The success of children, according to the participants, is achieved through good school. Children's education, for the participants, is one of the priorities in their life. They send their children to the best schools in Medan. They also supervise the children's learning progress at home. Participant 2 is one of the participants who is closely involved in supervising the education of their children. He made sure his children had a good education.

Interviewer: Do you still need to supervise the learning activities?

Participant 2: Still, I am still monitoring it (studying). I strictly keep monitoring and controlling kids' education.

When the participants stated that the meaning of shophouses is a business place, this also has an essential role in children's development process, especially from the financing aspect. Participants send their children to the best private schools in Medan, providing additional private courses outside of study hours. This effort requires much money. Currently, except for Participant 10 and Participant 9 , most of the participants' children are already in college. Some of them already got bachelors and got married. Participants 10 and Participants 9, send their children to one of the expensive private schools in Medan. Those who claim that one of the characteristics of quality of life is children's success. To achieve this, the participants made "a settlement strategy" by choosing a typology of shophouses, which could accommodate and support business functions. This building was chosen because of its location. At the same time, it can also accommodate the function of the house and was affordable for their economic capacity. With this choice, they live their lives in this buildings type by performing adaptations, physically with an appropriate arrangement of space (adjustment), and mentally with an accepting and grateful hearts. All participants explicitly stated that the shophouses positively affect the achievement of the quality of life they wish. A shophouse is a place where 'all life and ideals take place'.

Interviewer: So, related to what you want in life, what is the role of this shop?

Participant 10: Yes, there are many, for school children, our families ... yes, that's all from this building... so our life comes from shophouses, right ... Chinese people who don't have factories, right... they get income from shophouse...

Interviewer: To achieve a quality life, what kind of role does this shop house have?

Participant 8: Yes, you can say that it plays a role ... as our life too... fortunately our business takes place on several floors ... this is ... running all our lives here ... have a future even from this shophouse ...

\subsection{The Built Environment and Quality of Life: From the Initial Phase to the Advanced Phase}

Meanings can change along with changes in socio-culture and a person's life cycle [15]. This study captures the existence of 'continued aspirations' after the 'initial aspirations' phase. The participants' initial aspirations are running live in the shophouses and ready to face various problems in achieving their quality of life. 'Continued ideal' is the next phase, where the aspirations of the first phase have been achieved, and the next hope is to eliminate problems that previously had to be accepted.

This research shows that there are convenience and difficulty in occupying a shophouse. The primary convenience is, in the words of Participant 2, the shop-house building is 'the appropriate one.' The reason was, according to Participant 2, the shophouses are 'comfortable, safe, easy, everywhere near, very practical, good neighbors.' The other participant also stated that 'the shop has met their needs.' The essential needs are working, opening a business as a primary or side income source, and taking care of a family. Even if there are various problems, this will not be a big deal. The participants said that 'there are no obstacles to activity in the shop.' However, when asked whether they still wanted another house, most of the participants expressed that they still wanted it, provided when the finances were sufficient. It is a natural thing, considering that inhabiting is an ongoing activity to find a place in this world, which has never been fully achieved $[36,47]$.

\section{Conclusions}

This study has investigated how residents mean to the built environment, in this case, the shop house, plays a role in achieving the residents' quality of life. This research strengthens and enriches the theory of the interaction between humans and the built environment related to quality of life. The shophouse, which has meaning as a place to earn income, has various consequences in the experience of living in it. The residents of the shop houses have blended with their built environment, which is illustrated by the expression 'shop houses are all of our lives'.

This research can also explain the answers to questions 
related to 'what residents feel in living the phenomenon of living in a shophouse' and 'how the experience of experiencing this phenomenon is important and meaningful'. This study describes interactions that occur in the shophouse. Since the pre-occupation phase, the participants have already interactetd with the buildings, which continues at the post-occupation stage, and still occurs after achieving their quality of life. The activity is active, not passive, to 'create a home' and humans' continuous efforts to find its place in this world that has not been fully reached.

This research provides additional insight into the study of shophouses, where, among several obstacles, shophouses' existence plays a significant role in achieving its residents' quality of life. As a phenomenological study, this research has explained the specifics things regarding living in shophouse phenomena from the head of the family's point of view. Further research is expected to investigate the experiences of the children living in the shophouses and their plans for their future home types.

This study provides input on urban spatial planning that shophouses are a typology of urban buildings that support quality of life. In architectural design, this study has implications for how a multi-functional house occupant's life requires a flexible and multi-functional space, not strictly separating the public and private areas in the house.

\section{Acknowledgments}

We are very grateful to The Ministry of Research and Technology of the Indonesian Republic for supporting this study through the DRPM 2020 research grant. We really appreciate all participants and all supporting team in this research.

\section{REFERENCES}

[1] Rapoport, A. The meaning of the built environment, University of Arizona Press, Tucson (second edition), 1990.

[2] Jones, Ellen DunhamSeventy-Five Percent. Harvard Design Magazine no. 12/Sprawl and Spectacle. http://www.harvar ddesignmagazine.org/issues/12/seventy-five-percent, 2000.

[3] Dickinson, Duo. Architects design just $2 \%$ of all houses why?

http://commonedge.org/architects-design-just-2-of-all-hous es-why/ accessed 01 September 2018, 2016.

[4] Corni, Fransesco. Umm El Madayan, An Islamic City Through The Ages, Boston: Houghton Mifflin Company, 1993.

[5] Davis, H. Living over the Store: Architecture and Local Urban Life. New York: Routledge., Abingdon and New York, 2012.

[6] Zakaria, M. A., Kubota, T., \& Toe, D. H. C. The Effects of
Courtyards on Indoor Thermal Conditions of Chinese Shophouse in Malacca. Procedia Engineerin, 2015. https://doi.org/10.1016/j.proeng.2015.08.1094

[7] Aranha, J. The Southeast Asian shophouse as a model for sustainable Urban environments. International Journal of Design and Nature and Ecodynamics, 8(4), 325-335, 2013. https://doi.org/10.2495/DNE-V8-N4-325-335

[8] Dang, H. T., \& Pitts, A. Thermal environments and comfort perception in shophouse dwellings of Ho Chi Minh City. Proceedings of 10th Windsor Conference: Rethinking Comfort, 2018.

[9] Sari, L. H., Yuzni, S. Z., Haiqal, M., \& Evalina, Z. A review of spatial comfort in shophouse in humid tropics. IOP Conference Series: Materials Science and Engineering, 2018. https://doi.org/10.1088/1757-899X/352/1/012066

[10] Ginting, Y. U. U., Ginting, N., \& Zahrah, W. The spatial comfort study of shophouse at Kampung Madras. IOP Conference Series: Earth and Environmental Science, 2018. https://doi.org/10.1088/1755-1315/126/1/012008

[11] Puspitasari, Popi; Handjajanti, Sri, Precedent studies and visual architecture research: in search of the theoretical concept of Chinese shophouse façade style (Case: Kampung Cina, Pekalongan, Central Java, Indonesia), Proceeding International Seminar on Livable Space, 156-162, 2016.

[12] Eddy, F., Lindarto, D., Harisdani, D. D., \& Abdillah, W. The shophouse facade as a former of Medan City character identity. IOP Conference Series: Earth and Environmental Science, 2020.. https://doi.org/10.1088/1755-1315/452/1/0 12043

[13] Wan Ismail, W. H., \& Ching, L. H. Back Lanes as Social Spaces in Chinatown, Kuala Lumpur. Environment-Behavi our Proceedings Journal, 1(3), 293-299, 2016. https://doi.org/10.21834/e-bpj.v1i3.373

[14] Hasgül, Esin. Giving a meaning to space: influence of user identity in home environments. Proceedings of 3rd International Environment And Design Congress December, 2014.

[15] Turgut, Hulya; Emin Salgamcioglu2, Mehmet. (2019). Changing household pattern, the meaning and the use of home. Proceedings Of The 12th Space Syntax Symposium 8-13 July 2019, Beijing, China, Space Syntax Network / Sejong University Press

[16] Zhihua, Deng. House and Home: The Meaning Production of House and Family. Modern Anthropology 现代人类学, 2019, 7(2), 7-13 published Online April 2019 in Hans. http://www.hanspub.org/journal/ma

https://doi.org/10.12677/ma.2019.72002 文章引用: 邓志 华. 房与家: 房屋与家庭的意义生产 [J]. 现代人类学, 2019, 7(2): 7-13.DOI: 10.12677/ma.2019.72002

[17] Allassad Alhuzail, N. 'My private kingdom and sometimes my private jail' The of home in the lives of Bedouin women: changes in the home and social spaces and their implications for Bedouin women. Journal of Gender Studies, 27(6), 711-724, 2018. https://doi.org/10.1080/09589236.2 017.1301810

[18] Golabi, B., Bayzidi, Q., Tahmasbi, A., \& Sahabi, J., Deep 
Delving Into the Meaning of 'Native House' Through a Phenomenological Method:A Case Study of Rural Houses in Mokrian Area, Iran (Persian). Journal of Rural Research, 9(4), 646-661, 2019.http://dx.doi.org/10.22059/jrur.2018.2 52609.1220

[19] Dam, H., \& Eyles, J. "Home tonight? What? Where?" An exploratory study of the meanings of house, home and family among the former Vietnamese refugees in a Canadian city. Forum Qualitative Sozialforschung, 2012. https://doi.org/10.17169/fqs-13.2.1696

[20] Board, M., \& McCormack, B. Exploring the meaning of home and its implications for the care of older people, 2018. Journal of Clinical Nursing. https://doi.org/10.1111/jocn.1 4495

[21] Dekkers, W. Dwelling, house and home: Towards a home-led perspective on dementia care. Medicine, Health Care and Philosophy, 2011. https://doi.org/10.1007/s11019 $-011-9307-2$

[22] Andarini, R., Schranzhofer, H., Streicher, W., \& Pratiwi, A. K. Thermal simulation and cooling energy sensitivity analysis of a typical shophouse in Jakarta, Indonesia. IBPSA 2009 - International Building Performance Simulation Association 2009, January, 1887-1893, 2009

[23] Yaman Sokienah, "The Architectural and Interior Design Identity Crisis: The Case of Girne in North Cyprus," Civil Engineering and Architecture, Vol. 9, No. 1, pp. 124 - 129, 2021. DOI: 10.13189/cea.2021.090110.

[24] Dovey, K. " Home and Homelessness: Introduction " Kimberly Dovey. Home Environments. Human Behavior and Environment: Advances in Theory and Research, 8, 8485. 1985.http://link.springer.com/10.1007/978-1-4899-226 6-3_2

[25] Haarhoff, E., Beattie, L., \& Dupuis, A. Does higher density housing enhance liveability? Case studies of housing intensification in Auckland. Cogent Social Sciences, 2016. https://doi.org/10.1080/23311886.2016.1243289

[26] Wu, F., Liu, Y., Zeng, Y., Yan, H., Zhang, Y., \& Li, L. H. Evaluation of the human settlements environment of public housing community: A case study of Guangzhou. Sustainability (Switzerland), 2020.

https://doi.org/10.3390/SU12187361

[27] Du, P., Wood, A., Ditchman, N., \& Stephens, B. Life satisfaction of downtown High-Rise vs. Suburban low-rise living: A Chicago case study. Sustainability (Switzerland), 9(6), 1-15 (2017). https://doi.org/10.3390/su9061052

[28] Mojdeh Nikoofam, Abdollah Mobaraki , "Assessment of Quality of Life in the Urban Environment; Case Study: Famagusta, N. Cyprus," Civil Engineering and Architecture, Vol. 8, No. 5, pp. 860 - 872, 2020. DOI: $10.13189 /$ cea.2020.080513

[29] Nakhodaeezadeh, M., Jafarabadi, M. A., Allahverdipour, H., Matlabi, H., \& Dehkordi, F. R. Home Environment and Its Relation with Quality of Life of Older People. Journal of Housing for the Elderly, 2017. https://doi.org/10.1080/027 63893.2017.1280583

[30] Bloomberg, L., \& Volpe, M. Completing Your Qualitative Dissertation: A Roadmap from Beginning to End. In
Completing Your Qualitative Dissertation: A Roadmap from Beginning to End, 2012. https://doi.org/10.4135/9781 452226613

[31] Moustakas, C. E. Phenomenological research methods Clark Moustakas. Phenomenological Research Methods, 1994.

[32] Giorgi, A. (Ed.). Phenomenology and psychological research. Pittsburgh: Duquesne University Press, 1985.

[33] Patton, Michael Quinn. Qualitative research and evaluation methods Los Angeles: SAGE, 2015.

[34] Creswell, John W, Penelitian Kualitatif dan Desain Riset, Pusstaka Pelajar, 2014.

[35] Seamon, D. Phenomenology, Place, Environment, and Architecture: A Review. Environmental Architectural Phenomenology Newsletter, 2000.

[36] Heidegger, M., \& Hofstadter, A. Building Dwelling Thinking. Poetry, Language, Thought, 1971.

[37] Merleau-Ponty, Maurice. 2002. Phenomenology of Perception. New York: Routledge.

[38] Zahrah, W., Nasution, A.D., Urban Design Guidelines for Shophouses: A Temperature Modification Approach. Procedia - Soc. Behav. Sci. 2015. https://doi.org/10.1016/j. sbspro.2015.02.434

[39] Dukes, S. (1984). Phenomenological methodology in the human sciences. Journal of Religion and Health, 23(3), 197-203.

[40] Polkinghorne, D. E. (1989). Phenomenological research methods. In Valle, R. S. \& Halling, S. (Eds.), Existential-phenomenological perspectives in psychology (pp. 41-60). New York: Plenum Press

[41] Milleman, Alexander L. Phenomenological study of adoptive fatherhood: descriptions of life satisfaction provided by adoptive fathers bringing up adopted korean sons. (Electronic Thesis or Dissertation) 2016. Retrieved from https://etd.ohiolink.edu/.

[42] Kerns, J.D., Cooper, R., Brodersen, L., Gillespie, C., McMahill, J.M., McMahill, J.M., Learning at home: a phenomenology examining the perceptions of homeschooling parents regarding the social, emotional, and cognitive development of their children. J. Chem. Inf. Model. , 2016.

[43] Zahrah, W., \& Lie, S. People and Urban Space in Medan: An environment behaviour approach. Environment-Behavi our Proceedings Journal, 2016. https://doi.org/10.21834/ebpj.v1i1.235

[44] Zahrah, W., Loebis, M. N., Ginting, N., \& Aulia, D. N. Community perception and adaptation about living in shop house in Medan, Indonesia. IOP Conference Series: Earth and Environmental Science, 452(1), 2020. https://doi.org/10.1088/1755-1315/452/1/012020

[45] Rapoport, Amos. Human Aspect of Urban Form, Oxford: Pergamon Press, 1980.

[46] Seamon, D. Well-being and phenomenology: Lifeworld, natural attitude, homeworld and place. The Routledge 
Handbook of Well-Being, 99-105, 2017.

[47] Sharr, Adam. Heidegger for architects (Thinkers for Architects), Routledge, 2007.

[48] Rapoport, Amos. Culture, Architecture, and Design. Locke Science Publishing Co, 2005.

[49] Cummins, R. A. The golden triangle of happiness: essential resources for a happy family. International Journal of Child, Youth and Family Studies, 2018. https://doi.org/10.18357/i jcyfs 94201818638

[50] Sarwono, Sarlito Wirawan. Psikologi Lingkungan, Jakarta:
Gramedia dan Program Pascasarjana Program Studi Psikologi, Universitas Indonnesia, 1992.

[51] Osei-Tutu, E. M., \& Ampadu, E. Dimensions of couples' decision-making at home: The Ghanian experience. Journal of International Women's Studies, 2018.

[52] Pangaribowo, E. H., Tsegai, D., \& Sukamdi. Women's bargaining power and household expenditure in Indonesia: the role of gender-differentiated assets and social capital. GeoJournal, 2019. https://doi.org/10.1007/s10708-018-990 $1-4$

[53] Ingold, Tim. The Perception of the Environment Essays on livelihood, dwelling and skill. New York: Routledge, 2000. 